\title{
Informal Politics in the Management of Village Funds in Indonesia: Case in West Sumatra Province
}

\author{
$1^{\text {st }}$ Jenasti Viona ${ }^{1}, 2^{\text {nd }}$ Asrinaldi ${ }^{2}, 3^{\text {rd }}$ Tengku Rika Valentina \\ \{jenastiviona@gmail.com ${ }^{1}$, corresponding author: asrinaldi@soc.unand.ac.id ${ }^{2}$ \}
}

Postgraduate Student, Department of Political Science Andalas University, Indonesia ${ }^{1}$, Department of Political Science, Andalas University, Indonesia ${ }^{2}$, Department of Political Science, Andalas University, Indonesia ${ }^{3}$

\begin{abstract}
This article wants to explain the obstacles associated with the government's approach using the New-Institutionalism Approach, which emphasizes formal statutory rules in managing village funds. New-Institutionalism approach only focuses on implementing laws and ignores the community's norms, values, and beliefs, which hinder the emergence of innovation and creativity following resources in the village. This study used a qualitative approach with descriptive case study methods. This research uses semistructured interviews with 15 informants with various backgrounds such as Nagari apparatus, Nagari Deliberative Council, religious leaders, and traditional leaders. This article concludes that the Village Fund's rules in Nagari, West Sumatra Province, often change, are ambiguous, and contradict each other, making the Nagari Government challenging to manage the Village Fund. Whereas informal politics carried out by traditional elites in Nagari is an essential dimension in the New-Institutionalism Approach, which is rooted in state regulations and Nagari society. However, there are still many Nagari in West Sumatra that has not taken advantage of existing socio-cultural values that hinder the success of achieving the Village Fund's goals in this area.
\end{abstract}

Keywords: New institutionalism approach, regulation, government, and village funds

\section{Introduction}

The Village Fund Program is assistance provided by the central government to each village to create an independent and prosperous village. Every year the government always increases the amount of Village Fund revenue. For example, the Village Fund allocated in 2019 amounted to 70 trillion rupiahs and increased to 72 trillion in 2020. This increase also impacted Indonesia's average Village Fund revenue, which had increased to 960 million rupiahs per village in 2020. Indirectly, the addition of the Village Fund shows the government's seriousness to improve the welfare of village communities. To ensure this welfare's achievement, the government oversees the use of this Village Fund by the village community. Several regulations were issued, such as Law No.6 of 2014 concerning villages as the primary basis for implementing this Village Fund to its derivatives in the form of ministerial regulations and other regulations.

The issuance of regulations in implementing the Village Fund implies the government's concern about the Village Fund's misuse. Moreover, the village government so far has no experience in managing large development budgets. The government's concern about abuse is 
evident. A new phenomenon in the implementation of the Village Fund program is an increase in corruption cases involving village elites in managing the Village Fund. The Indonesian Corruption Watch (ICW) report recorded 181 cases in 2018, with state losses reaching 40.6 billion rupiahs [1]. In fact, in 2019, corruption cases in the village budget sector were most prosecuted by law enforcement officials than other sectors. ICW data shows 46 corruption cases in the village budget sector out of 271 corruption cases during 2019. Village budget corruption was recorded to have caused state losses of up to $\mathrm{Rp} 32.3$ billion [2].

The many rules regarding the management and utilization of the Village Fund are indeed a preventive strategy implemented by the government to reduce cases of misuse of the Village Fund. The limited experience of village officials in planning development and budgeting, which is not easy, impacts these Village Fund corruption cases. Instead of preventing the Village Fund's corruption, the village government has difficulty developing creativity and innovation in utilizing the Village Fund. There are quite a lot of statutory regulations governing the use of Village Funds. They come from Law No. 6/2014 on villages and Government Regulation (PP) No.43 of 2015 concerning the implementation of the Village Law as amended by PP No.11/ 2020 regarding the second amendment to PP No.43 / 2014, which previously also changed the PP on the implementation of this Village Law, namely PP No.47 of 2105. Almost every year, the Ministry of Villages and Disadvantaged Regions Development issues many regulations for the management and utilization of Village Fund; this is under the targets set.

This article wants to explain the Village Fund's management in West Sumatra Province and its relation to informal politics in Nagari. Nagari in West Sumatra is an autonomous customary community unit that carries out its household affairs. Nagari certainly reflects the implementation of the lowest governmental functions, but there are also genealogical and sociocultural aspects that live and develop in the community. Therefore, the practice of Nagari governance will be different from that of the village government because of Kerapatan Adat Nagari (KAN) and Musyawarah Tungku Tigo Sajarangan (MTTS), which reflect the dimensions of informality that exist in the Nagari. Formally the Nagari government has the duties and authorities as stipulated by Law No.6 / 2014 on villages. However, informally, the Nagari government's running is also heavily influenced by the informal elite, Ninik Mamak, a religious leader and local intellectual in the Nagari. This article will explain how the informal elite's existence with the power they have affects the management and utilization of Village Funds in Nagari in West Sumatra.

\section{New Institutionalism Approach in Village Fund Management}

The many regulations in managing village funds make it difficult for the village government to harmonize its duty and authority in implementing village governance. The government inevitably uses a more formal approach to implementing development and empowerment activities in the village. This phenomenon is paradoxical with the nature of the village, which relies a lot on informality aspects that live and develop in the community [3]. Not to mention the problem of overlapping legislation made by the government in the context of managing this Village Fund. For example, there is disharmony between the Permendes and PDT with the Pemendagri regarding the management of Village Funds. The existence of conflicting regulations influences village officials to understand the Village Fund.

One of the impacts is that many village heads have been caught in legal cases implementing Village Fund management because they do not understand the existing laws and regulations. Psychologically, the legal case that ensnared village government officials also created fears from 
the village elite in using the Village Fund. As a result, the village elite lost their creativity and innovation to accelerate the improvement of the village community's welfare. The formal and standardized Village Fund management rules ignore the different aspects of each village's norms and culture. This reality certainly has a significant influence on community participation in the management of the Village Fund.

To provide the expected direction and targets in the management of this Village Fund, the government has compiled several laws and regulations based on Law No.6 of 2014 concerning villages and Law No.23 of 2014 concerning regional governance. The implementation of the Village Fund involves three central ministries, namely the Ministry of Finance (Kemenkeu), the Ministry of Home Affairs (Kemendagri), and the Ministry of Villages (Kemendes), which have their respective authority. For example, in terms of fostering governance, the Ministry of Home Affairs is doing it; the Ministry of Health and PDT supervises the implementation of infrastructure development; and how the Ministry of Finance allocates the Village Fund. However, unfortunately, all of these ministries issue their respective policies, which sometimes cause difficulty in coordination about the material of the legislation, which impacts the village fund's use by the community in the village.

This Village Fund's existence greatly assists the village government in carrying out their autonomous authority, especially in carrying out their household affairs. The Law regulates what these matters are, but its implementation is often constrained. One of the obstacles is in the aspect of financing village household affairs. Before receiving the Village Fund, the village government and village household affairs' implementation only depended on the Village Fund Allocation (ADD), which was very limited in number. Even the funding for the operational affairs of the village government also comes from this ADD. As a result, the village's development program is highly dependent on the implementation of projects originating from the district offices implemented in the village. The absence of development costs for this village has an impact on the progress of villages in Indonesia.

The issuance of Law Number 6 of 2014 concerning villages recognizes legal and customary entities that need to be strengthened as the basis for development that starts in the village. Moreover, the Jokowi administration has made the Village Fund Program the basis for the sustainable development of decentralization in Indonesia to realize the welfare of rural communities. This law places the village as a region that has its autonomy. The village also recognizes the existence of original and traditional rights in regulating and managing the local community's interests and playing a role in realizing the ideals of independence based on the 1945 Constitution of the Republic of Indonesia. This village government's duties and authorities will not be able to be carried out if it is not accompanied by financing. Therefore, the government has also prepared a procedure for implementing the Village Fund's financial regulations by issuing PP No. 43 of 2014 concerning implementing village financial management regulations. This PP aims to realize effective and efficient village financial management. Besides, this law's issuance can also realize good village governance based on three main pillars, namely transparency, accountability, and participation.

Even so, the large number of laws that govern Village Funds is a problem for village governments in managing village finances. It is indicated that village government officials are confused with existing regulations, which impact the government and village communities' inability to optimize the Village Fund they receive. Moreover, the government asks village officials and their citizens to refer to the statutory rules they set as guidelines. Even though the results of a study by the Corruption Eradication Commission (KPK) found that the problems of Village Funds stemmed from regulations on the use of Village Funds based on PP No. 22 of 2015 is not transparent enough and only emphasizes the aspect of equity. Although there have 
been improvements through changes to the management of this Village Fund, the spirit of transparency and accountability in the village has not yet been realized.

For example, a phenomenon that occurred in West Sumatra Province. With Nagari's existence as the lowest government unit based on the community's genealogy and socio-cultural system, governance practices certainly cannot be done because there is an informal dimension that involves all residents in Nagari. Unfortunately, the Village Fund management in Nagari tends to be formal with binding rules. Without realizing it, this ignores the dynamics that occur in the community, which causes the implementation of Village Funds to be not optimal. The Nagari people in West Sumatra Province live with a dimension of informality from their social and cultural systems. In practice, this system also helps the Nagari government carry out its functions [4]. Many problems faced by the village government can be resolved using this informal approach. The existence of traditional elites in Nagari became an inseparable part when informal politics became an essential part of carrying out the Nagari government's functions. Likewise, in managing the Village Fund, which is an essential instrument in the village's development implementation.

The existing trend, the government is trying to use the New Institutionalism Approach in implementing its policies. This approach tends to prioritize normative references to guide, limit, and control actors' organization and behavior so that it can give shared meaning to social behavior [5]. This approach places institutions as structures, rules, procedures that apply in society. This approach explains that institutions are the primary tool in forming social constructions, where the existing social constructions in society will shape the prevailing political system and habitus [6]. Therefore, it is not surprising that the New Institutionalism Approach places the state as the main actor in policy-making and implementation.

This approach places the government in a dominant position as the organizer of state power following the state's goals and interests. The government, as a state institution, exercises its power formally concerning society. According to Newton and van Deth [7], government structure as a formal institution is the main actor in formulating regulations related to the implementation of its functions in society. For example, in the Village Fund management, which places the lowest level of government, such as the village government, formulates practical rules for how to use the Village Fund. Through this approach, the government controls in detail how the village community uses the Village Fund. Unfortunately, the implementation of this government regulation ignores the realities that exist in village communities. The dominance of the New Institutional Analysis Approach in the management of the Village Fund impacts the implementation of development programs in villages. In the village community, there are hereditary habits that come from their social and cultural systems that influence how the village government carries out its functions.

Moreover, Nagari's social and cultural systems are part of the lowest governance administration in West Sumatra. The management of Village Funds is not sufficient just based on formal rules from the government. The informal elite's influence on community life in Nagari determines the achievement of the Village Fund goals. In planning and compiling programs through the Village Fund's use, the village government implements the existing standard procedures. For example, there is a process of brainstorming ideas at an early stage for each village to identify and accommodate the community's aspirations. Furthermore, holding a development planning meeting (Musrenbang) involves the village government, traditional elites, and other community representatives. Unfortunately, in its implementation, the rules in this Musrenbang tend to be rigid and formal, even incompatible with the village community's social and cultural system. With an implementation that emphasizes formality, the bureaucracy has not been able to meet the village community's needs. Local government intervention by 
placing the sub-district bureaucracy to supervise and control the Village Fund utilization implementation increasingly dominates every village activity that utilizes the Village Fund.

\section{Methodology}

This research uses a qualitative approach with a case study instrument method, a case study method to explain issues in the management of Village Funds in West Sumatra. This study interviewed 15 informants from various backgrounds with a semi-structured format such as wali Nagari and their apparatus, informal leaders, traditional and religious leaders, and activists from non-governmental organizations in the Nagari. Besides, this study also uses secondary data from government documents, journalistic reports from print and online mass media, and other data sources from research results, both published and unpublished. In this study, data analysis used descriptive qualitative methods by grouping and categorizing data according to the research objectives.

\section{Finding and Discusion}

\section{Regulatory Barriers in Village Fund Management}

With a large amount of the Village Fund budget for each village, the government has prepared various laws and regulations to regulate the Village Fund utilization implementation. The government considers this rule to prevent wrong planning that causes state losses and has implications for legal problems. The laws and regulations governing the Village Fund management consist of rules governing village development and village communities' empowerment. However, the complexity of the laws and regulations governing the management of Village Funds raises new problems in village governance. Village leaders have lost their ability to manage the Village Fund due to the binding standard rules that change yearly. This regulation creates confusion for the village government to utilize and use the Village Fund. Besides, each ministry's numerous laws and regulations responsible for the utilization of the Village Fund cause overlapping in its implementation [8].

The same phenomenon also occurs in the village government or what is known as Nagari in West Sumatra Province. The Nagari government lost the ability to use the Village Fund for the benefit of Nagari builders. The village government must adjust its development planning with existing laws and regulations. There are still many purposes for providing this Village Fund that is not following its objectives. The failure to provide the Village Fund is indeed a problem in West Sumatra and many Indonesia regions. One of the causes is the lack of understanding of the village apparatus regarding the village's regulations and its derivatives. The emergence of this problem is closely related to the low quality of Human Resources in Nagari. On the other hand, the local government also did not understand how to interpret the law related to the village. In fact, in terms of utilization of Village Funds and reporting, the Village Funds are still not by statutory regulations to impact the disbursement of Village Funds in the next period.

Not only that, several cases of fraud in the management of Village Funds occurred in West Sumatra. For 2019, four cases in the management of Village Funds, Head of the West Sumatra Province Community and Village Empowerment Service (DPMD); Syafrizal Ucok, said four cases of misappropriation of Village Funds by village officials in the local area [9]. 
The many problems that occur in the management of the Village Fund in West Sumatra show how the village elites have not understood the rules for managing the Village Fund. Complicated bureaucratic rules and overlapping laws, both between the ministries involved in the Village Fund regulations, make it increasingly difficult for village elites to innovate to manage the Village Fund.

The exciting thing about the management of this Village Fund is the prioritization of formal rules in utilizing the Village Fund, which is often contrary to the customs of the people in Nagari, which tend to be informal and prioritize cultural aspects, local norms, and customs. The government's statutory rules override things that develop in the village community so that they have an impact on the management of the Village Fund. Even the management of the Village Fund does not get a response from the village community because it does not address community needs. Although Law No. 6/2014 clarifies and recognizes customary rights, in its application, these rules cannot be implemented, due to intervention and control by the government in formal and hierarchical management, following existing regulations.

The government's tendency to use a formal and multilevel approach in implementing Musrenbang at the village level eliminates other alternatives that have become a habit of the community. This formal approach in the development process binds the community with rules that limit the mechanism, timing, method, and type of proposals when communities in Nagari participate in the development, for example, in proposing development using the Village Fund. Even though the village people live with their habits that tend to be informal, which they practiced long before the government introduced the formal mechanisms for this development, this informal mechanism manifests the existing social capital to build up the area through small groups in the public space [10]. People used to talk about development issues in their Nagari through conversations at the Lapau (tavern) every night after working in the fields or the garden. The community freely gives their views in the discussion so that all problems will arise along with alternative solutions. This custom has been going on for a long time and is not officially institutionalized. This custom is an essential part of informal politics in developing development policies in the Nagari in West Sumatra. Almost all Nagari have open public spaces like this Lapau, which also serve as information centers for residents to discuss their Nagari issues.

The people living in Nagari are rich in culture, norms, values, and customs. This value encourages people to work together and cooperate to help fellow communities and in the administration of village governance. Likewise, traditional leaders in Nagari have a significant role in society. With this custom, the Nagari community can help how the Nagari government manages the Village Fund. Unfortunately, this social and cultural system has not been appropriately utilized in managing the Village Fund in Nagari. For example, in Solok Selatan District, there are still many planning processes in the utilization of Village Funds that have not been on target [11]. In general, Nagari's development is more focused on physical development, which negates community empowerment programs. Even programs implemented through the use of Village Funds in Nagari rarely touch directly what the community needs. Planning and preparation of development programs have also not considered the people's traditional and cultural values in Nagari. As a result, activities in the Village Fund management do not get the attention and support of the Nagari community.

The Nagari government considers more formal rules based on legislation by ignoring the social and cultural systems developed in society. The mainstreaming of the New Institutionalism Approach provides space for formal rules and flexibility for informal actors who also influence realizing governance goals. However, failure to understand this approach at the grassroots level failed to provide the Village Fund's objectives. It appears that the government has deliberately 
chosen a neo-institutionalism approach by ignoring actors outside the Nagari Government and giving a significant role to government actors in managing the Village Fund.

The large amount of the Village Fund Budget received by Nagari is why the government uses this approach. Therefore, in the planning process, the Village Fund's management tends to limit community participation because of regulations that prioritize a formal approach. This condition indirectly illustrates how the government doubts the community's ability in the village to manage the Village Fund. They are practicing a social and cultural system that can implement the existing formal rules. The New Institutionalism approach presented in the management of the Village Fund itself did not work well in Nagari West Sumatra. Indeed, one of the obstacles that become the Nagari Government's reason is the limited human resources in Nagari, thus giving a more significant role to formal institutions in implementing development planning in Nagari through the use of Village Funds. Unfortunately, this mechanism keeps people away from participating in building their Nagari.

The Nagari Government in West Sumatra Province has not utilized the social and cultural system of the people in Nagari to build their Nagari through Village Funds, which are increasing in number every year. The regulations governing the Village Fund's management give great authority to the Nagari Government apparatus. As a result, the traditional elites do not supervise the Village Fund's management, causing a misappropriation of Village Funds. The New Institutionalism approach has become a paradox to provide this Village Fund. The impetus for the emergence of creativity and innovation based on Nagari's local wisdom has not yet emerged. On the other hand, the New Institutionalism Approach raises a new problem: the further distance people are from the customs and culture that are part of their daily lives. The government believes the New Institutionalism approach can guard well in the Village Fund management process to maintain this system.

The New Institutionalism approach in managing the Village Fund, which the government uses through the implementation of the existing rules in the management of the Village Fund, has resulted in the community starting to lose confidence in the government. As a result, the community feels they have no responsibility for the activities carried out by the Nagari Government. The most apparent change from the implementation of the Neo-Institutionalism Approach is the waning of the social and cultural system of the people in Nagari, especially their involvement in participating in development planning and preparation through the use of the Village Fund.

\section{Conclusion}

This article has explained how complex and overlapping regulations in Village Fund management affect Nagari in West Sumatra Province. The dominant role of the Nagari Government in planning and formulating development programs by utilizing the Village Fund through the New Institutionalism Approach negates the existence of an informal elite. The informal elite in Nagari has an essential role in overseeing the administration of Nagari governance. Moreover, in the administration of Nagari governance and formal institutions such as Wali Nagari (village heads) and their apparatus, there is also a customary institution known as Kerapatan Adat Nagari (KAN). This KAN consists of Ninik Mamak representing the tribes in Nagari who occupy the Jorong (Dusun). Usually, the development base in Nagari is in Jorong, involving this informal elite. Unfortunately, the New Institutionalism approach, which prioritizes formal rules in the management of Village Funds, forgets that there are informal rules in Nagari, which also contribute to the success of Nagari's development goals. 
The use of the New Institutionalism Approach in the management of Village Funds in Indonesia, especially in West Sumatra, has not met community expectations. Even the Nagari government officials failed to improve the welfare of the community in Nagari because the Village Fund's utilization was not optimal. Moreover, with the government's tight control through the rules for managing the Village Fund, the Nagari community loses the motivation to participate under the people's social and cultural system in Nagari. Interestingly, the New Institutionalism Approach's implementation raises new problems, namely the occurrence of government domination of the Nagari Government through the use of Village Funds that are not following community expectations.

\section{Acknowledgments}

This research was funded by the Ministry of Research and Technology with a contract number T/63/UN.16.17/ PTM-Sosial Humaniora/2020

\section{References}

[1] Ihsanuddin, (2018), ICW: Ada 181 Kasus Korupsi Dana Desa, Rugikan Negara Rp 40,6 milyar. https://nasional.kompas.com/read/2018/11/21/19000481/icw-ada-181-kasuskorupsi-dana-desa-rugikan-negararp-406-miliar?page=all (Accessed on 28 Agustus 2020).

[2] Ramadhan, A (2020), Catatan ICW, Kasus Korupsi Dana Desa Terbanyak Muncul Pada 2019. https://nasional.kompas.com/read/2020/02/18/19084421/catatan-icw-kasus-korupsidana-desa-terbanyak-muncul-pada-2019 (Accessed on 20 September 2020).

[3] Asrinaldi dan Viona, J (2020). Politik Informal Dalam Pembangunan Desa dan Implikasinya Pada Penguatan Demokrasi Lokal di Indonesia. Analisis CSIS 49(2): 228-248.

[4] Asrinaldi (2017), Demokrasi Lokal di Indonesia: Otonomi, Nagari dan Sistem Sosial Budaya di Sumatera Barat. Padang: Rumah Kayu Publishing.

[5] Finkenbusch, P (2017), Rethinking Neo-Institutional State Building: The Knowledge Paradox of International Intervention. New York: Routledge.

[6] March, J.G, and Olsen, J. P (1984), The New Institutionalism: Organizational Factors in Political Life. American Political Science Review 78 (3): 734-749.

[7] Newton, K. \& van Deth, J (2010), Foundations of Comparative Politics: Democracies of the Modern World. $2^{\text {nd }}$ (ed.). New York: Cambridge University Press.

[8] Suryowati, E (2017), Banyaknya Aturan Soal Dana Desa Dinilai Membingungkan. https://nasional.kompas.com/read/2017/09/05/17443621/banyaknya-aturan-soal-danadesadinilai membingungkan?page=all (Accessed on 28 Agustus 2020).

[9] Antara (2019), Libatkan Wali Nagari dan Bendahara, Empat Kasus Hukum Terjadi di Sumbar. $\quad$ https://sumbar.antaranews.com/berita/289846/libatkan-wali-nagari-danbendahara-empat-kasus-hukum-terkait-dana-desa-terjadi-di-sumbar (Accessed on 28 Agustus 2020).

[10] Tsay, L. L (2007), Accountability without Democracy: Solidary Groups and Public Goods Povision in Rural China. New York: Cambridge University Press.

[11] Viona, J (2020), Permasalahan dalam pengelolaan Dana Desa, Studi Kasus Nagari Lubuk Gadang Timur Kecamatan Sangir Kabupaten Solok Selatan. Tesis, Magister Ilmu Politik, Universitas Andalas, Padang. 